\section{Results}

Once the team had divided the costs for multiple affiliation entrances, it then produced a schedule of assessments for each affiliated institution. The assessment for each institution was divided into portions for organized research, clinical care, teaching. coursework, and other purposes. This distribution enabled the institutions to pass on the charges to third parties. The team also produced a schedule of unit charges for the services paid for directly by users.

\section{Advantages of this Approach}

This approach, while necessitating a careful cost accounting and user survey effort, has several significant advantages over others used to recover service costs from library users.

This approach permits detailed justification of cost recovery because cost calculations and survey responses directly produce usage charges and institutional assessments. An audit trail becomes available for auditors from the institutions and the federal government who will wish to trace their assessments back to supporting detail. The approach is readily understandable to financial executives who are responsible for making decisions about library financial support.

Moreover, this approach builds a strong foundation for financial planning. Library administrators can use the databases to compare alternative strategies of service pricing, user charges, institutional assessments, and individual membership fees.

Editor's Note: For more information on the consulting firm that advised the Countway Library, contact Rousmaniere Management Associates, Inc., Hearthstone Plaza, Suite 206, 111 Washington St., Brookline, MA 02146.

\title{
New Accreditation Criteria Proposed
}

\author{
Edward G. Holley, Dean \\ School of Library Science \\ The University of North Carolina \\ at Chapel Hill
}

At its' annual meeting on December 13, 1982 , Thomas G. Carpenter (Memphis State) and Emmett B. Fields (Vanderbilt) presented a formal draft of new Criteria for Accreditation (Proposed) to the College Delegate Assembly of the Commission on Colleges of the Southern Association of Colleges and Schools. The culmination of three years' work by four task forces, the Criteria for Accreditation was hailed by Fields as the boldest move of the Commission on Colleges since 1962. Moreover, although individual sections of the 1962 standards have all been revised during the later sixties and seventies (a library section was added to the Graduate Standard in 1969 and the Library Standard was revised in 1975), this is the first complete revision of SACS standards for colleges and universities in twenty years. If approved by the College Delegate Assembly at its December 1983 meeting in New Orleans, the Criteria for Accreditation will replace the current standards during the next three years.

Emphasis in the new criteria is placed upon educational outcomes assessment and an ongoing planning process. To quote Carpenter, "The new Criteria for Accreditation presented here represent a retention of the most important elements of the old standards which have served the Commission on Colleges well throughout the past several decades, and it includes the addition of new elements, particularly a st ronger emphasis on planning and educational outcomes assessment, which will help the Commission serve its constituents more effectively in the future." Stated simply the new criteria ask colleges and universities to determine what effect a college and university has on students, i.e., "what difference does a college education make?" The corollary to that approach might be stated as "What effect does a college or university library have on students?" i.e., "What difference does a college library make?"

In the process of overhaul of the current standards, the author and Gerald Sandy, director of the library at Armstrong State College, Savannah, Georgia, served as members of the Study Committee on Services and Support. Included under Educational Support Services are the Library, Student Development Services, Computer Services, and Instructional Support. Although the Library Section is similar to Standard 6 in the current document, the emphasis in the proposed document is upon the library user, in line with the general thrust of the criteria. The Library Section should therefore be studied in conjunction with Section III, Institutional Effectiveness, which discusses "Outcomes Assessment" and "Planning." As readers will note, SACS has under preparation a manual with "guidelines and suggestions for the development and use of outcomes assessment programs and measurement instruments."

Both Sections III and Section 5.2 are given be low. 


\section{SECTION III \\ Institutional EfFECTIVEnESS}

\subsection{Outcomes Assessment}

Professional judgment and experience within higher education have led to the conviction that certain environments, resources, processes, and structures normally promote learning. These elements are addressed in the other sections of the Criteria for Accreditation. The ultimate measure of the effectiveness of an educational institution, however, is its educational outcomes-the success of its students in acquiring knowledge, competencies, and skills and in learning their meaningful application; in forming attitudes and in gaining values and perspectives; and in developing the capacity for further learning. In its statement of purpose, goals, objectives, and completion requirements for its educational programs, each institution must state its view of what constitutes de sirable outcomes which may include service and research functions, as well as student educational achievement. These desired outcomes must be appropriate to the purpose of the institution and the characteristics of the learners it serves.

The Commission on Colleges requires that each institution demonstrate its continuing concern for student educational achievement through a planned program of outcomes assessment characterized by the following elements:

1. The institution has defined its major educational goals and objectives in terms that lend themselves to assessment.

2. The institution has defined the "effectiveness indicators" (i.e., the types of evidence and levels of achievement) to be used in assessing its effectiveness in achieving its goals and objectives.

3. The institution has established the organization and mechanisms for assessment and has implemented an assessment program in a systematic manner

4. The institution uses the results of its assessment in institutional planning and decisionmaking to improve the quality of its programs.

It is essential that the institution assign administrative responsibility for the outcomes assessment function and that it periodically evaluate the effectiveness of that function. There must be overall coordination of all institutional elements involved in outcomes assessment.

The outcomes assessment program of an institution should be designed to incorporate the follow. ing elements:

- Institutional purpose

- Characteristies of students and other constituencies served

- Educational program

- Student educational achievement

- Physical resources

- Human resources

- Financial resources

- Support services
- Administrative services

- Governance

In addition to the above, institutions may need to identify other matters of concern to be included in their outcomes assessment activity.

Within certain administrative units of an institution, it is necessary to identify goals and objectives that are not stated in terms of student achievement (e.g., management function goals) but which ultimately translate into the support and facilitation of student learning. Evaluation of effectiveness of management and support properly constitutes another dimension of outcomes assessment.

The Commission does not prescribe any single process or format for an institution's program of outcomes assessment, and it recognizes, indeed, urges that some assessment procedures and instruments will be locally developed. Where available and appropriate, however, assessment instruments that permit comparisons against external norms should also be considered. *

\subsection{Planning}

If outcomes assessment is to have meaning and value it must ultimately result in institutional improvement and thus must become a significant factor in institution decision-making and planning. A well-defined planning program which is properly staffed and implemented is essential to the orderly growth and development of an institution.

Institutional organization for the planning function will vary, depending upon the size, complexity, and purpose of the institution, but in every case the product of this function should be a planning document. The plan must:

- Reflect the purpose of the institution.

- Show that attention has been given to the results of outcomes assessment.

- Identify and discriminate among alternative courses of action.

- Anticipate budget and other resource availabi] ity and provide for contingencies.

- Contain provisions for periodic review.

- Have the endorsement, approval, and acceptance of the governing board.

It is essential that the institution assign administrative responsibility for the planning function and that it periodically evaluate the effectiveness of that function. There must be overall coordination of all institutional elements involved in planning.

\subsection{Library}

Because the library is essential to the achievement of the educational goals of students and fac-

*The Commission will have available a supplementary document which provides guidelines and suggestions for the development and use of outcomes assessment programs and measurement instruments. This document also describes commercially available materials and discusses institutional planning. This document may be ordered from the Southern Association of Colleges and Schools Publications Office. 
ulty, each institution must have a library which provides the primary and secondary materials needed to support its purposes and programs; these resources should be available in a well-equipped, readily accessible facility which encourages maximum utilziation by the campus community. To facilitate use of such resources, both on and off campus, a competent professional staff must be available to assist the users. The collections of print and non-print materials must be well organized, and adequate hours must be maintained to insure accessibility to users.

Priorities for acquiring materials and establishing services must be determined with the needs of the users in mind. Thus, with the active cooperation of the administration, faculty, students, and library staff, each institution must develop for its library a statement of mission and objectives consistent with the institutional purpose. The library must be evaluated regularly and systematically to insure that it is meeting the needs of its users and supporting the programs and objectives of the institution.

\subsubsection{Services}

Basic library services include formal instruction, individual user assistance, bibliographic access to information, and materials access.

The library must provide programs for users which may include instruction in library use, lectures, library guides and user aids, self-paced instruction, and computer-assisted instruction.

The library must offer point-of-use instruction, personal assistance in conducting library research (including term paper consultations), and traditional reference service by telephone and by mail as well as in person. Professional assistance should be available at convenient locations when the library: is open.

The library must provide adequate records of on-campus materials through locally produced catalogs, indexes, and bibliographies, access to information sources regardless of location through standard indexes and bibliographies, and, where appropriate, access to external bibliographic databases.

The library must have adequate physical facilities to house, service, and make the library collections easily available; up-to-date equipment in good condition for using print and non-print materials; provision for rapid access to any remotely stored materials: provision for interlibrary loan agreements; and an efficient and appropriate circulation system. The library must provide students with opportunities to learn how to access information in a variety of formats so that they can continue life-long learning. In order to insure that students learn the application of library skills to the solution of particular problems, librarians must work in close cooperation with the teaching faculty in assisting students to use resource materials effectively.

An institution must provide appropriate library services at off-campus locations where credit courses are offered to insure that these courses receive the same level of library support as that given to equivalent on-campus courses. This obligation can be met by developing a branch library or by making contractual arrangements with libraries in the geographic area. Competent library personnel should be assigned the planning duties entailed in providing these services and in ascertaining their continued adequacy. When contractual agreements are reached, they must specify the level of service and type of access to be provided for students and faculty.

\subsubsection{Collections}

The library collections must be sufficient to support the educational, research, and public service programs of the institution. Institutions offering graduate work need library resources substantially in excess of those required for the bachelor's degree. Since diverse methods and needs of instruction and research exist on any campus, no one group is able to understand the breadth and depth of collection requirements. It is essential, therefore, that librarians, teaching faculty, and researchers share involvement in the development of collections and that the institution establish policies defining such involvement.

Each library must have a written policy which defines the qualifications, roles, and responsibilities of those involved in the selection and weeding process.

\subsubsection{Staff}

Most members of the professional library staff must hold professional degrees at the graduate level in library science or learning resources; however, professional or technical training in specialized service areas are increasingly important in meeting user needs. An adequate support staff must be provided to carry out responsibilities of a nonprofessional nature: qualifications for these positions should be defined by the institution in terms of skills needed.

The chief librarian must be a well-qualified professional who administers the services in a manner which contributes to the educational effectiveness of the institution. Organizational relationships, both external and internal to the library, should be clearly specified. Institutional policies concerning promotion, salary, tenure or contractual security, and faculty status for library personnel must be clearly defined and made known to all personnel at the time of employment.

\subsubsection{Institutional Relationships}

In order to increase the ability of the library to provide the resources and services needed by its users, cooperative relationships with other libraries and agencies may be considered. These cooperative relationships must not be used by institutions to avoid responsibility for providing their own adequate and accessible library resources and services. In all cases of cooperative arrangements, formal agreements must be established, thereby safe- 
guarding the integrity and continuity of library resources and services. An institution which contracts with other institutions to provide its students with library services must demonstrate that its students are using these services.

Copies of the proposed Criteria for Accreditation were distributed to Presidents and/or other representatives of member institutions at the meeting of the Commission Colleges on December 13. Librarians may review the criteria by asking their presidents for a copy. Librarians are also encouraged to send data on effectiveness measures to the Commission offices for incorporation into the resource manual mentioned in the footnote on Section III. I cannot stress too strongly the importance of sharing with the Commission staff recommen- dations on questions which should be asked in selfstudies and by visiting teams. While recognizing that the state of the art of effectiveness measurement is not well developed, librarians must make available to our SACS colleagues information about the strongest research tools we now have on educational outcomes. The Manual will be of critjcal importance in the interpretation of the Criteria and this is our chance to have a hand in the preparation of that important document.

Suggestions, comments, or recommendations should be sent as soon as possible to Elbie Conard, Assistant Executive Director, Commission on Colleges, Southern Association of Colleges and Schools, 795 Peachtree Street, N.E., Atlanta, GA 30365 .

\section{Highlights of the Midwinter Meetings of the ACRL Board of Directors}

The Board of Directors of the Association of College and Research Libraries met twice during the ALA Midwinter Meeting: on Saturday, January 8, 1983, and Wednesday, January 12, 1983.

\section{Chapters}

The board approved the recommendation of the Chapters Council that $\$ 3.50$ per member be allocated for direct chapter support.

\section{College \& Research Libraries}

The board voted to reappoint C. James Schmidt editor of $C \& R L$ for an additional year until June 20,1984 , allowing for a six-month period in which a new editor will act in an apprentice capacity to the current editor.

\section{Committees}

The board approved the dissolution of the Ad Hoc Copyright Committee and the creation of a standing Copyright Committee. A revised charge for the Legislation Committee was also approved.

The board amended the ACRL Bylaws to prohibit members of standing committees from serving more than four consecutive years.

\section{Discussion Groups}

The board referred a petition for the formation of a College Librarians Discussion Group to the College Libraries Section's Executive Committee to see whether the needs of such a group could be met within the section.

The board approved the formation of a Women's Studies Discussion Group, and approved the dissolution of the Audio-Visual Discussion Group and the transfer of its activities into the AudioVisual Committee.

\section{Executive Director}

The board approved adoption of a procedure for an annual review of the executive director to begin with an executive session at the Fall 1983 Executive Committee meeting.

\section{Jones/Howard Award}

The board approved ACRL co-sponsorship with other ALA divisions of a proposal submitted for the J. Morris Jones and Bailey K. Howard ALA Goal Award to enhance divisional leadership within ALA. The program would run from April 1983 to June 1986.

\section{Legislation}

The board approved the request of the Legislation Committee to endorse the reauthorization of the Library Services and Reconstruction Act with the recommendation that Section 304(c) be changed to state that nothing in Section 304 shall prohibit the reimbursement for resource sharing activities on the part of participating libraries.

\section{Membership}

The board requested the ACRL Membership Committee to examine the feasibility of offering ACRL/ALA memberships renewable on their anniversary date rather than at the end of a fixed membership year. The Committee will explore the option with the ALA Membership Committee and report back to the board.

\section{National Conferences}

The board requested access to data on papers submitted for ACRL national conferences, including the number of intents to submit, the actual number of papers submitted, the percentage of papers accepted, and the percentage of papers rejected at a later stage of review. 